\title{
Risks in Housing and Real Estate Construction Project
}

\author{
Madhav Prasad Koirala \\ Shingania University, Rasjasthan, India \\ Corresponding Email: madhavkoirala9@gmail.com
}

\begin{abstract}
The main purpose of this paper is identify the risks involved in housing and real estate of construction projects in Nepal and ranks them as per the severity. In this research, first the risks involved in construction projects life cycle has been identified with the help of professional expertise and verified with the help of housing profession arranged in a respondent in systematic hierarchical structure. Questionnaire surveys and literature review were used for data collection. Next, based on the obtained data a network was based on the statically system has been designed for the evaluation of project risks. After data analysis, the result has been published and finally conclusion has been drawn.
\end{abstract}

Keywords: risk identification, risk ranking, construction projects.

\section{Introduction}

Risks in housing and real estate in construction projects are the chances of occurrences of events which affect the objectives and hence it will be lost the productivity within the project life cycle. According to [9], risk is as a condition of the real work in which there is an exposure to adversity. More specifically, risk is a condition in which there is a possibility of an adverse deviation from a desired outcome that is expected or hoped for. In the same way, [5] has also tried to define risks as the exposure to the "chance of occurrences of events adversely or favorably affecting project objective as a consequence of uncertainty" Therefore Risk is a potential event that, if it occurred would have a negative impact on the project time, cost or quality.

\section{Starting Point}

Management involve planning, organizing, staffing, leading or directing, and controlling an organization (a group of one or more people or entities) or effort for the purpose of accomplishing a goal. Resourcing begins the deployment and manipulation of human resources, financial resources, technological resources, and natural resources.

During management organization is another important pre-requisite entity which can be viewed as system, and to manage the human action also called management and it includes design, to facilitate the production of a useful output from the system. It is also known as the opportunity to 'manage' oneself, to attempting to manage others.

Risk Management is defined as a formal orderly process for systematically identifying, analyzing and responding to risk events throughout the life of a project to obtain optimum degree of risk elimination or control [5]. Risk management is a scientific approach of identifying, anticipating and minimizing the possible adverse impacts on the projects. Risk Management is a set of processes concerned with conducting risk management planning, risk identification, risk analysis, response planning, and monitoring and control on a project. 
Urbanization became sensitive when people started migrating from villages to cities. According to [8], it was continuing when Lichhabi were ruling in Kathmandu. In recent days, it has been characterized by unplanned and unmanaged settlement. Consequently, citizens are using low qualities of amenities. In different cities of Nepal, urbanization process is growing day by day. As per [2], migrant pattern is growing from rural. Detail description is given in the table 1 . Migrant from urban in Nepal is less compare to rural. Similarly migrant from outside to Nepal is least one compare to other two.

Table 1: Migrant population (all ages) sex, current location and origin of last migration

\begin{tabular}{|c|c|c|c|c|c|c|}
\hline \multirow[b]{2}{*}{$\begin{array}{l}\text { Reason for last } \\
\text { migration }\end{array}$} & \multicolumn{3}{|c|}{ Number (in thousands) } & \multicolumn{3}{|c|}{ Percentage } \\
\hline & $\begin{array}{l}\text { Currently } \\
\text { located in } \\
\text { urban area }\end{array}$ & $\begin{array}{l}\text { Currently } \\
\text { located in } \\
\text { rural area }\end{array}$ & $\begin{array}{c}\text { Total } \\
\text { migrant } \\
\text { population }\end{array}$ & $\begin{array}{l}\text { Currently } \\
\text { located in } \\
\text { urban area }\end{array}$ & $\begin{array}{l}\text { Currently } \\
\text { located in } \\
\text { rural area }\end{array}$ & $\begin{array}{l}\text { Total } \\
\text { migrant }\end{array}$ \\
\hline From urban Nepal & 233 & 326 & 559 & 12.8 & 5.4 & 7.1 \\
\hline From rural Nepal & 1388 & 4900 & 6288 & 76.5 & 81.3 & 80.2 \\
\hline From outside Nepal & 193 & 799 & 993 & 10.7 & 13.3 & 12.7 \\
\hline Total persons & 1814 & 6026 & 7840 & 100.0 & 100.0 & 100.0 \\
\hline $\begin{array}{l}\text { Persons by current } \\
\text { location }\end{array}$ & & & & 23.1 & 76.9 & 100.0 \\
\hline & & & & & & urce: [2] \\
\hline
\end{tabular}

From above data housing and real estate demand can be expected more in coming year. To fulfill the shelter's need, integrated and systematic housing are growing. Similarly, peoples' aspiration for modern housing is also increasing because costumers are influenced by western culture. In the other hand Nepal is suffer from decade long civil insurgency and people have migrated from village to cities seeking opportunity, security and improved physical facilities. Every one's desire to have their own house where they are working is natural desire. This has incorporated development of housing and real estate business as a separate and distinct economic sector. After enactment of Joint Housing Act in 1997, there is a rise in developers and real estate entrepreneurs in Nepal. This sector being a newer, rapidly growing economic sector of the country and contributing in terms of revenue, employment and using local construction materials. During operating its services, is growing in the conflict ridden and politically instable environment, might have confronted with various types of risks. In this context, this study will attempts to explore the risks facing by this sector and analyze the causes and consequences of the risks for systematic enhancement of this sector so that it can serve as one of the major and reliable economic sector of the country.

Shelter is one of the basic needs for human beings not only for protection against unwanted environmental event with including hostile weather, but also for maintaining standard of living acceptable to family or even to elevate one's position in the society through enhanced living status. It is well known that Nepal is land locked country surrounded three sides by India and one south side by China being developing country too the total population was estimated on 2008 period 23.5 million by [2]. That population is managing over 147181 sq.km of the area. It 
has fifty eight municipalities city including one metropolitan city, two sub metropolitan cities. According to the Ministry of Local Development, there are 99 municipals in the country now with four sub-metropolitan cities - Lalitpur, Pokhara, Biratnagar and Birgunj (Himalayan times, July 27 2011). It is including one metropolitan city. There are 3,783 village development committees and 75 district development committees in the country. The government has declared 41 municipals by merging 132 VDCs (Himalayan times, July 27 2011). The intensity of population pressure became high in cities due to the opportunities and facilities will be more and attracts from the village where the opportunities and amenities are less.

Table 1 shows the population density of major cities of Nepal and also can assume the growing pattern intensity of population in each year. From the above data it is found migration towards cities from rural becoming ongoing process unless government promotes to villagers by means of special facilities.

Developers are facing tremendous risk in housing and real estate even it was manageable because, this is the period of civil insurgency ended by doing agreement between government and Maoist, so the people want to be own house in cities and do some business in cities where security and physical facilities are available.

\section{Problem in housing and real estate}

Housing and real estate is rapidly growing one of new sector in Nepal and also suffering from various adversities. It is also observed that the recent crisis observed in financial institutions of the country is the consequence of the investment on this sector. However, no systematic effort has been initiated either by government or by professionals to study the role that has been played by this sector in national economy as well as the risks associated in this sector. The first problem is price of land increased in the cities consequently the price of housing and real estate also increased. Secondly more people invested their money on land and liquidity problem seen on the economy of the country so that bank and financial institution stop to invest in this sector, thirdly Bank and financial institution increased the interest rate. Fourth the political system became unstable and there is no clear policy from government to monitor and control the unmanaged land polling (plotting) and housing, apartment system. Beauty of the city has become worse as compared to Nepali's original median period. Regulating this has not been effective. Dispute has been arising about the ownership within the neighbor because of the lack of open space. Safety and security to the citizens has become big problem during construction and maintenance period. To address the same this type of research study, which explores the construction risk management. Therefore, this study will be a pioneering work and will provide a firm basis and future direction for housing and real estate companies in Nepal. Similarly, it will also help government for formulating and revising its policies affecting this sector.

\section{Objective of the Research}

The main objective of this research was to identify the risks and rank them in housing and real estate projects which support the successful application of risk management in construction projects in Nepal. The result of this study are expected to provide useful guidelines for forming and operating effective and in housing and real estate projects both in Nepal and in other similar economies. 


\section{Overview of Risk Management in Housing and Real estate in Nepal}

Construction work being risky and complex by nature, there are chance for disputes [4]. Developers are facing the risk due to unclear policy of government. It is observing that some projects are saleling even before taking final approval from the authority. Political, social, environmental, technical and dispute risk are being as usual.

The table given below is the projection of population by [6] on Feb, 2005 and published by central bureau of Statistic, Nepal.

Table 2: One Century of Population Change in Nepal, 1911-2011

\begin{tabular}{|c|c|c|c|c|c|}
\hline \multirow{2}{*}{$\begin{array}{l}\text { Census } \\
\text { Year }\end{array}$} & \multirow{2}{*}{ Population } & \multicolumn{2}{|c|}{$\begin{array}{l}\text { Between-census change } \\
\text { in population }\end{array}$} & \multirow{2}{*}{$\begin{array}{l}\text { Geometric } \\
\text { growth rate } \\
\text { (percent) }\end{array}$} & \multirow{2}{*}{$\begin{array}{l}\text { Persons } \\
\text { per sq. } \\
\text { km. }\end{array}$} \\
\hline & & Number & Percent & & \\
\hline 1911 & $5,638,749$ & $\ldots$ & $\ldots$ & - & 38.31 \\
\hline 1920 & $5,573,788$ & $-64,961$ & -1.15 & -0.13 & 37.87 \\
\hline 1930 & $5,532,574$ & $-41,214$ & -0.74 & -0.07 & 37.59 \\
\hline 1941 & $6,283,649$ & 751,075 & 13.58 & 1.16 & 42.69 \\
\hline $1952 / 54$ & $8,256,625$ & $1,972,976$ & 31.40 & 2.30 & 56.10 \\
\hline 1961 & $9,412,996$ & $1,156,371$ & 14.01 & 1.65 & 63.96 \\
\hline 1971 & $11,555,983$ & $2,142,987$ & 22.77 & 2.07 & 78.52 \\
\hline 1981 & $15,022,839$ & $3,466,856$ & 30.00 & 2.66 & 102.07 \\
\hline 1991 & $18,491,097$ & $3,468,258$ & 23.09 & 2.10 & 125.64 \\
\hline 2001 & $23,151,423$ & $4,660,326$ & 25.20 & 2.27 & 157.30 \\
\hline $2011 *$ & $28,584,975$ & $5,433,552$ & 23.47 & 2.13 & 194.22 \\
\hline \multicolumn{6}{|c|}{ *Projection (Medium Fertility Decline Variant) } \\
\hline \multicolumn{6}{|c|}{$\begin{array}{l}\text { Sources: Central Bureau of Statistics, 2003; Population Monograph of Nepal, Central } \\
\text { Bureau of Statistics and Ministry of Population and Environment. 2003; Population } \\
\text { Projections for Nepal 2001-2021. }\end{array}$} \\
\hline
\end{tabular}

From the above table 2, the population by 2011 will reach about $28,584,975$ and it will be 194.22 people per square kilometer. Therefore every one can assume housing business will more important and the risk management during implementation is challengeable in coming years.

As per the tenth five year plan (2002-2007), long term concept was under clause no 21.3 and it is mentioned that the uncontrolled urbanization in the main cities will be mange through physical planning which will build good relationship with rural area, affect due to seismic will be minimize housing management work will be given to developers or real estate holders to develop the cost effective by adopting good skill and technology. In the same article, the objectives were urbanization development, Urban and Rural residence and Building. All the above objectives will be related under real estate and housing, which is possible by enhancing the private investors in this sectors. 
Housing and real estate was became profitable business from 2001 to 2006 period and did good profit. In the past more investors develop the housing and real estate haphazardly not even maintaining the level of standardization and quality. As the rural area was threat of killing for those who are not support to insurgencies. Therefore developers could manage to build and provide the housing and real estate even they were feeling lot of risks as mentioned above.

Table 3: Some Housing and apartment developed and price

\begin{tabular}{|l|c|c|c|c|}
\hline \multicolumn{1}{|c|}{ Offers } & Location & Product type & Units & $\begin{array}{c}\text { Unit cost } \\
\text { (in million } \\
\text { rupees) }\end{array}$ \\
\hline Kathmandu Residency & Bagdole & Apartments & 123 & $1.8-2.5$ \\
\hline Mount View Residency-I & Harisiddhi & Apartments/Duplexes & 70 & $1.3-1.7$ \\
\hline Mount View Residency-II & Hattiban & Apartments & 140 & $3.0-4.0$ \\
\hline The Comfort Housing & Sitapaila & Standalone houses & 60 & $1.6-3.7$ \\
\hline Sunrise Homes & Balkumari & Apartments/ Duplexes & 102 & $2.0-2.8$ \\
\hline Civil Homes & Bhainsepati & Standalone houses & 59 & $0.7-1.1$ \\
\hline Subha Avas & Naya Naikap & Duplexes & 75 & $0.7-1.5$ \\
\hline Oriental Colony & Kuleshwor & Apartments & $500+$ & $1.2-2.8$ \\
\hline Shangrila Villa & Gangabu & Apartments/Duplexes & 36 & $3.8-5.2$ \\
\hline Grace Apartments & Naxal & Apartments & 56 & $1.8-2.5$ \\
\hline
\end{tabular}

Source: Nepali Times, ISSUE \#98 (14 JUNE 2002 - 20 DEC 2002)

In the table 4 given below shows, the owner with own house in Nepal less than 90 percent, where as the people who live in rented house are about 9 percent, similarly it shows more than $46 \%$ have their own house and more than $51 \%$ people lives in rented.

Table 4: Distribution of households by occupancy status

\begin{tabular}{|l|c|c|c|c|}
\hline Description & Owned & Rented & Others & Total \\
\hline Nepal & 89.2 & 9.2 & 1.7 & 100.0 \\
\hline Urban & 61.5 & 61.5 & 35.7 & 100.0 \\
\hline Kathmandu valley & 46.6 & 51.6 & 1.8 & 100.0 \\
\hline Eastern/Central Hill/Mt. & 70.0 & 26.6 & 3.5 & 100.0 \\
\hline "West"/hill/Mountain & 61.3 & 35.7 & 3.0 & 100.0 \\
\hline Eastern Terai & 70.6 & 25.2 & 4.3 & 100.0 \\
\hline Central Terai & 70.1 & 27.8 & 2.2 & 100.0 \\
\hline "West" Terai & 73.3 & 23.5 & 3.2 & 100.0 \\
\hline $\begin{array}{l}\text { "West" refers to western, mid-western and far-western development region NLFS } \\
\text { (Nepal Labor Force Survey) }\end{array}$
\end{tabular}

(Source: [2]) 
According to Ichhya Tamang who is the president of Nepal Land and Housing Development Association (NLHDA) which was established in 1994, sees the demand for housing going up because of urbanization and an economy buoyed by remittances. "Kathmandu valley is growing annually at the rate of 6,500 new houses, there are more than 30 housing companies but they don't create more than 2,000 houses a year," says Tamang.

After looking the data mentioned above that, the demand of housing and real estate is not yet saturated. The nature of demand is more in cities compared to the village. Similarly more in urban compared to the small cities.

\section{Theoretical Approach of Risks}

In the figure 1 given below, Risks in housing and real estate project in Nepal, in the centre there is risk management. In each project cycle, there will have the identification of risk, analysis of risks, responding of risk and monitoring and controlling of risks that to be analyzed. Every process there will be causes and effects. For example risk identification can be done by means of updating the risk register, making the plan as per received information, adopting correction action, Programming Change Request (PCR), updating to risks identification check list for future construction projects.

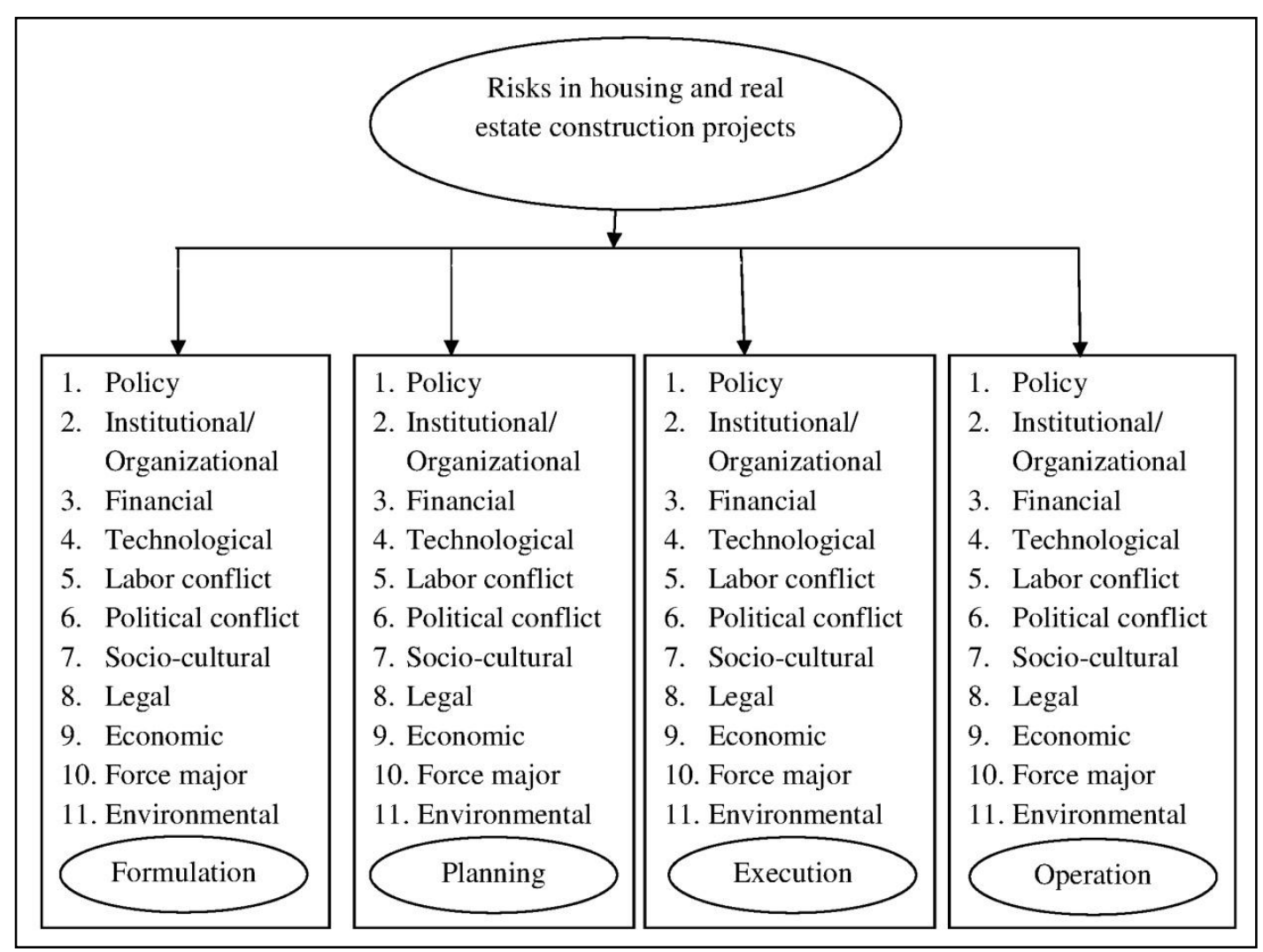

Figure 1: Risks in Housing and real estate in project life cycle

Once the risks identification work is over then how sensitive the risks are that must be analyze properly. For that work, qualitative and quantitative analyzing will be done to know the risk 
level, consequences and likelihood, hazard and risk's impact. The third step is response of probable risks. Depending upon the rank or the level of risks, it will be as per the rank of risks. Generally there will acceptance of risk if the level is low, risk will reject or avoidance if the level of risks is high. Also as per the level of risks will be mitigate the risk or try to reduce the risk. The fourth and last one is transferring the risks, which is in practicing. For example transfer the risks to insurance company by paying the money. In the last stage, risks monitor and control will be applied in the upcoming project by converting risk to opportunity. For applying it potential risk exposure has to kept, the risks whatever identified, that has to classify, similarly construction of risk curve or risk mapping is essential, for monitoring control of construction project.

As discussed in figure 1,risks in housing and real estate in project cycle, based on received information, the identification, rank them, the response and the result with conclusion about the risks in housing and real estate research study has been successfully conducted which is not yet done in Nepal.

Generally, during implementation phase the risks will be more sensitive beginning in project conceptualization and end by handover phase. The contractor, consultant and developer have to carefully manage those risks by treating it as opportunities.

Some of the common risks can be classified mainly six types as follows:
1) Policy
2) Institutional/Organizational
3) Financial
4) Technological
5) Labor conflict
6) Political conflict
7) Socio-cultural
8) Legal
9) Economic
10) Force major
11) Environmental

\section{Methods and Methodology}

Questionnaire surveys were distributed to (19) respondents who are Developers engineers and who are registered under the Nepal Housing and Land Association. A response rate of fiftypercent $(52 \%)$ was obtained. The purpose of the questionnaire survey was intended for a better feedback on the extent of the use of arrangement and the risk rank during their housing and real estate projects. The 2 nd part of the research involved an in-depth interview which involved (5) participants from various public and private companies. It was carried out with the senior managers to provide detail information on the background, knowledge and experience of housing project and the risks that occurred in project life cycle of projects and ways to overcome them. 
Table: 5 Rank of risks in housing and real estate

\begin{tabular}{|c|c|}
\hline Risks in Project formulation Phase & Risks Project Execution Phase \\
\hline 1. Risks related with the policies & 1. Risks related with the policies \\
\hline $\begin{array}{l}\text { 2. Risks associated with institutional and } \\
\text { organizational }\end{array}$ & $\begin{array}{l}\text { 2. Risks associated with institutional and } \\
\text { organizational }\end{array}$ \\
\hline 3. Risks associated with financial & 3. Risks associated with financial \\
\hline 4. Risks associated with Technology & 4. Risks associated with Technology \\
\hline 5. Risks related with labor conflict & 5. Risks related with labor conflict \\
\hline 6. Risks associated with political conflict & 6. Risks associated with political conflict \\
\hline 7. Socio-cultural risks & 7. Socio-cultural risks \\
\hline 8. Risks associated with Legal & 8. Risks associated with Legal \\
\hline 9. Risks related with economic & 9. Risks related with economic \\
\hline 10. Risks associated with force major & 10. Risks associated with force major \\
\hline Risks in Project Planning Phase & Risks in Operation or close up phase \\
\hline 1. Risks related with the policies & 1. Risks related with the policies \\
\hline $\begin{array}{l}\text { 2. Risks associated with institutional and } \\
\text { organizational }\end{array}$ & $\begin{array}{l}\text { 2. Risks associated with institutional and } \\
\text { organizational }\end{array}$ \\
\hline 3. Risks associated with financial & 3. Risks associated with financial \\
\hline 4. Risks associated with Technology & \multirow[t]{7}{*}{ 4. Risks associated with Technology } \\
\hline 5. Risks related with labor conflict & \\
\hline 6. Risks associated with political conflict & \\
\hline 7. Socio-cultural risks & \\
\hline 8. Risks associated with Legal & \\
\hline 9. Risks related with economic & \\
\hline 10. Risks associated with force major & \\
\hline
\end{tabular}

Most of risks that the professionals are being faced on their respective site are mentioned above in the figure. Those risks are tactfully deal by the developer, consultant and contractor during particularly in implementation phase. 
Table 6: Results and Analyses

\begin{tabular}{|c|c|c|c|c|c|c|}
\hline S.N & & Min & Max & Mean & S.D & Rank \\
\hline A & $\begin{array}{l}\text { Housing and real Estate Project Formulation } \\
\text { Phase }\end{array}$ & & & & & \\
\hline 1 & $\begin{array}{l}\text { Consultation with legal expert for project } \\
\text { makes the confidentiality? }\end{array}$ & 0 & 4 & 1 & 0.949 & 3 \\
\hline 2 & $\begin{array}{l}\text { Do you agree that weak analysis of appraisal } \\
\text { invite uncertainty? }\end{array}$ & 0 & 4 & 1 & 0.949 & 4 \\
\hline 3 & $\begin{array}{l}\text { Project identification play great role to know } \\
\text { many risks issues? }\end{array}$ & 0 & 6 & 1 & 1.581 & 1 \\
\hline 4 & $\begin{array}{l}\text { Sometimes stakeholders usually appear non- } \\
\text { unanimous which turn in risk? }\end{array}$ & 0 & 5 & 1 & 1.265 & 2 \\
\hline 5 & $\begin{array}{l}\text { Financial strategies taken by the stake holders } \\
\text { come across uncertainty? }\end{array}$ & 0 & 2 & 1 & 0.316 & 9 \\
\hline 6 & $\begin{array}{l}\text { Civil insurgency or wars create risks to choose } \\
\text { the projects? }\end{array}$ & 0 & 2 & 1 & 0.316 & 10 \\
\hline 7 & Imported new technology may create problem? & 0 & 3 & 1 & 0.632 & 6 \\
\hline 8 & $\begin{array}{l}\text { The perceptions of political parties towards } \\
\text { particular projects need to analyze? }\end{array}$ & 0 & 3 & 1 & 0.632 & 7 \\
\hline 9 & $\begin{array}{l}\text { Site suitability is an environment factor which } \\
\text { must be explore? }\end{array}$ & 0 & 4 & 1 & 0.949 & 5 \\
\hline 10 & $\begin{array}{l}\text { Better to minimize unsuitable policies taken } \\
\text { during formulation of projects? }\end{array}$ & 0 & 3 & 1 & 0.632 & 8 \\
\hline B & $\begin{array}{l}\text { Housing and real Estate Project Planning } \\
\text { Phase }\end{array}$ & & & & & \\
\hline 1 & $\begin{array}{l}\text { Unfair evaluation of tender leads serious } \\
\text { problems? }\end{array}$ & 0 & 3 & 1 & 0.632 & 4 \\
\hline 2 & $\begin{array}{l}\text { Consultations with land professional before } \\
\text { purchasing help to identify the problem? }\end{array}$ & 0 & 3 & 1 & 0.632 & 5 \\
\hline 3 & $\begin{array}{l}\text { Incomplete, defective, inadequate specification } \\
\text { and tender document and design change loss to } \\
\text { project? }\end{array}$ & 0 & 3 & 1 & 0.632 & 6 \\
\hline 4 & $\begin{array}{l}\text { Planning permission delay from government } \\
\text { makes loss to productivity? }\end{array}$ & 0 & 2 & 1 & 0.316 & 9 \\
\hline 5 & $\begin{array}{l}\text { Good management of resource reflects the best } \\
\text { capabilities of project manager and directs } \\
\text { toward the opportunity? }\end{array}$ & 0 & 2 & 1 & 0.316 & 8 \\
\hline 6 & $\begin{array}{l}\text { Procedural delay makes big problem during the } \\
\text { planning phase? }\end{array}$ & 0 & 2 & 1 & 0.316 & 10 \\
\hline 7 & $\begin{array}{l}\text { Financial short is terrible risk because project } \\
\text { may stop in any condition? }\end{array}$ & 0 & 3 & 1 & 0.632 & 7 \\
\hline
\end{tabular}




\begin{tabular}{|c|c|c|c|c|c|c|}
\hline 8 & $\begin{array}{l}\text { Availability/experience of geotechnical } \\
\text { consultant explores the risks? }\end{array}$ & 0 & 5 & 1 & 1.265 & 1 \\
\hline 9 & $\begin{array}{l}\text { Right decision at right time to assign } \mathrm{A} / \mathrm{E} \\
\text { consultants is also a problem? }\end{array}$ & 0 & 5 & 1 & 1.265 & 2 \\
\hline 10 & $\begin{array}{l}\text { In planning phase, land acquisition, housing } \\
\text { policies must be project friendly? }\end{array}$ & 0 & 4 & 1 & 0.949 & 3 \\
\hline $\mathrm{C}$ & $\begin{array}{l}\text { Housing and real Estate Project Execution } \\
\text { Phase }\end{array}$ & & & & & \\
\hline 1 & $\begin{array}{l}\text { Management risks of men, machine, material, } \\
\text { manager, minute, and money must be use in } \\
\text { right way at right time to enhance the } \\
\text { performance of the project? }\end{array}$ & 0 & 4 & 1 & 0.949 & 5 \\
\hline 2 & $\begin{array}{l}\text { Skilled \& experience Construction Manager } \\
\text { minimizes the construction risks? }\end{array}$ & 0 & 4 & 1 & 0.949 & 6 \\
\hline 3 & $\begin{array}{l}\text { Incomplete design/ drawing/ instruction create } \\
\text { problems in the project? }\end{array}$ & 0 & 5 & 1 & 1.265 & 1 \\
\hline 4 & $\begin{array}{l}\text { Safety in construction site enhances the } \\
\text { productivity of the project? }\end{array}$ & 0 & 5 & 1 & 1.265 & 2 \\
\hline 5 & $\begin{array}{l}\text { High performance or quality expectations leads } \\
\text { unproductively in the output? }\end{array}$ & 0 & 3 & 1 & 0.632 & 8 \\
\hline 6 & $\begin{array}{l}\text { Procedural delay makes big risk in the } \\
\text { execution phase? }\end{array}$ & 0 & 3 & 1 & 0.632 & 9 \\
\hline 7 & $\begin{array}{l}\text { Unsuitable construction program planning } \\
\text { creates problem to run the project? }\end{array}$ & 0 & 4 & 1 & 0.949 & 7 \\
\hline 8 & $\begin{array}{l}\text { Unavailability of sufficient amount of money } \\
\text { leads risk in real estate project? }\end{array}$ & 0 & 5 & 1 & 1.265 & 3 \\
\hline 9 & $\begin{array}{l}\text { Unsuccessful management team (human } \\
\text { resource) team creates internal risks? }\end{array}$ & 0 & 5 & 1 & 1.265 & 4 \\
\hline 10 & $\begin{array}{l}\text { Inappropriate erecting or lying out of projects } \\
\text { invites the risk? }\end{array}$ & 0 & 3 & 1 & 0.632 & 10 \\
\hline D & $\begin{array}{l}\text { Housing and real Estate Project operation } \\
\text { Phase }\end{array}$ & & & & & \\
\hline 1 & $\begin{array}{l}\text { How important an environment creates the } \\
\text { risk? }\end{array}$ & 0 & 5 & 1 & 1.265 & 1 \\
\hline 2 & How financial problem arise in this phase? & 0 & 4 & 1 & 0.949 & 3 \\
\hline 3 & $\begin{array}{l}\text { Question of legality regarding the property is it } \\
\text { risky? }\end{array}$ & 0 & 3 & 1 & 0.632 & 4 \\
\hline 4 & $\begin{array}{l}\text { The economy of nation and international also } \\
\text { create problems/ }\end{array}$ & 0 & 5 & 1 & 1.265 & 2 \\
\hline
\end{tabular}




\section{Conclusion}

As housing and real estate become more global and more complex, involving more developers, more professional contractors and more specialist consultants and generating more invention controlling and monitoring that information will become an increasingly important part of the risk management process which replaces the unusual work that is being practiced.

Housing and real estate act and policy, socio-economic, political stability should be in favor of housing and real estate for minimize the risk and professional practice that can mitigate the risk, which is good practice of project management, and management based collaboration is a tool that can mitigate the risk against some of the most common causes of loss, disputes, delays and quality issues which potentially undermine the success of a project.

\section{References}

[1] Three Year Interim Planning, 2005/06 - 2007 /08, National Planning Commission, Nepal.

[2] Nepal Labor Force Survey II, 2008, Centre bureau of statistics, Nepal

[3] Base Paper of Three Year, 2010/11 - 2012/13, 2010 May/ June, National Planning Commission, Nepal.

[4] Adhikari, R. P., (2008). Construction Disputes and its Resolution, Federation of contractors' association Nepal, Nepalese Construction Souvenir.

[5] Al-Bahar, J. (1988). Risk management approach for construction projects: a systematic Analytical approach for contractor, PhD. thesis, University of California, Berkeley, CA.

[6] Bastola, T. S, and Radhakrishna, G. C. (2005), One hundered years of census Taking in Nepal: The 2011 Census, Centre bureau of statistics, Nepal.

[7] Himalayan News Service (July 27, 2011) The Himalayan Times daily newspaper, International Media Network Nepal Pvt. Ltd, APCA House, Baidya Khana Road, Anam Nagar, Kathmandu, Nepal.

[8] Levi, S. (1905). Le Nepal etude Historique d'un royaume hindou (vols.I-III), Paris, Ernest Leroux.

[9] Vaughan, E. (1997). Risk management, Wiley, New York. 